J. Clin. Chem. Clin. Biochem.

Vol. 17, 1979, pp. 725-729

\title{
Macro-Creatine Kinase-BB: Observations on 6 Patients $^{1}$ )
}

\author{
By G. Chemnitz,
}

Division of Gastroenterology and Hepatology, Medizinische Hochschule Hannover

Evangelia Jockers-Wretou,

Institute of Organic Chemistry, Biochemistry and Isotope Research of Stuttgart University,

E. Schmidt, F. W. Schmidt and J. Lobers

Division of Gastroenterology and Hepatology, Medizinische Hochschule Hannover

(Received May 11/August 29, 1979)

In Memory of Professor Dr. Gábor Szász

Summary: From 2000 sera with elevated total creatine kinase (EC 2.7.3.2) activity the sera of 6 patients showed a persistent high and anamnestically inexplicable creatine kinase activity level. The serum isoenzyme pattern was analyzed by four different methods. Electrophoresis revealed an atypical creatine kinase activity band located between creatine kinase-MM and creatine kinase-MB. An adequate estimation of the persistent enzyme activity could only be achieved by immunotitration (immunoprecipitation), which identified the creatine kinase activity as due primarily to the isoenzyme creatine kinase-BB. Other methods (immunoinhibition and column chromatography) may lead to misinterpretations. The atypical serum creatine kinase-BB showed a higher molecular weight $\left(M_{\mathrm{r}}=250,000\right)$ and altered substrate affinity as compared to native creatine kinase-BB. Both properties are attributable to the binding of creatine kinase-BB to immunoglobulins.

\section{Makro-Kreatinkinase-BB: Beobachtungen an 6 Patienten}

Zusammenfassurig: Unter etwä 2000 untersuchten Seren mit erhöhter Aktivität der Kreatinkinase (EC 2.7.3.2) fielen die Seren von 6 Patienten mit einer konstanten und anamnestisch nicht erklärbaren Kreatinkinase-Aktivität auf. Das Isoenzymverteilungsmuster wurde mit 4 verschiedenen analytischen Methoden differenziert. Die Elektrophorese zeigte jeweils eine einzige Kreatinkinase-Bande, die zwischen Kreatinkinase-MM und Kreatinkinase-MB lokalisiert war. Eine spezifische Zuordnung gelang nur mit Hilfe der Immuntitration (Immunpräzipitation), die die Kreatinkinase-Aktivität als vorwiegend aus dem Isoenzym Kreatinkinase-BB bestehend identifizierte. Die Ergebnisse der Immuninhibition und der Säulenchromatographie können zu Mißdeutungen führen. Die atypische SerumKreatinkinase-BB-Aktivität im Serum war sowohl mit einem Molekulargewicht von $M_{\mathrm{r}} 250,000$ als auch hinsichtlich ihrer Substrataffinität von nativer Gewebs-BB verschieden. Beide Eigenschaften sind auf eine Bindung zwischen Kreatinkinase-BB und Immunglobulinen zurückzuführen.

\section{Introduction}

In the last three years repeated reports have appeared on atypical isoenzyme distribution of creatine kinase (EC. 2.7.3.2) (1-8). Electrophoretic investigations $(3,4$, $5,7)$ show an enzyme activity located between creatine kinase-MM and creatine kinase-MB. However, immunological determination methods prove this isoenzyme

1) Supported by the Deutsche Forschungsgemeinschaft activity to be creatine kinase- $\mathrm{BB}$ (2). The cause of the cathodic location is assumed to be an elevated molecular weight of creatine kinase-BB as a result of association with immunoglobulins $G$ and $A(5,8)$. At present there is no recognizable connection with uniform etiological or pathogenetic factors.

From approximately 2000 patients with elevated creatine kinase activity we found an atypical isoenzyme distribution pattern in the sera of 6 patients. The 
patients manifested a regularly detectable and anamnestically inexplicable increase in total creatine kinase activity. The creatine kinase-MB activity in the serum was usually higher than total activity after application of the immunoinhibition test (MERCK-1-TEST-CK-MB). This observation led us to characterize the isoenzyme distribution in greater detail by further analytical methods, to define the substrate affinity in comparison with the other isoenzymes by kinetic investigations, and to determine the molecular weight by gel filtration.

\section{Materials and Methods}

The total creatine kinase activity was measured with a GSHactivated and - after the introduction of the $\mathrm{N}$-acetylcysteine (NAC) recommended as an activator by the German Society for Clinical Chemistry (9) - with an $\mathrm{N}$-acetylcy steine-activated creatine kinase-test kit. The creatine kinase-MB activity was determined with MERCK-1-TEST-CK-MB (Cat. No. 14300, initially GSH-activated, later NAC-activated) by immunoinhibition (10) of the creatine kinase-M subunits. The isoenzymes were specifically differentiated by immunotitration (immunoprecipitation $(11,12)$ ) with anti-creatine kinase-MM and anti-creatine kinase-BB (both anti-sera from MERCK, Cat.No. 11642 and 11643), the residual activities being meas: ured after precipitation ( 1 hour at $+37^{\circ} \mathrm{C}$ and 15 hours at $+4^{\circ} \mathrm{C}$ ) and centrifugation (Eppendorf centrifuge, $5 \mathrm{~min}$ at $9,000 \mathrm{~g}$ ) with an $\mathrm{N}$-acetylcysteine-activated creatine kinasekit. Reference studies were performed by a modification of Mercer's column chromatography technique (13) (TCBOEHRINGER, Cat.No. 189219). Measurements were performed with an Eppendorf photometer, $334 \mathrm{~nm},+25^{\circ} \mathrm{C}$.

The electrophoresis was carried out on cellulose acetate strips (SCHLEICHER \& SCHÜLL) with a constant voltage of $200 \mathrm{~V}$, over a period of 1 hour. The bands containing creatine kinase activity were developed under UV light after 30 minutes of incubation of the strips on a agarose-substrate (NAC-BOEHRINGER) mixture. Strips that had been incubated without creatine phosphate served as controls. As a reference serum we used that of a patient with severe intoxication (to tal creatine kinase activity $7000 \mathrm{U} / \mathrm{l}$, creatine kinase-MB fraction 0.04 ) enriched with the same amount of human creatine kinase-BB.

The molecular weight was determined with calibration proteins (BOEHRINGER) by gel filtration (Sepharose-6B, column $600 \times 25 \mathrm{~mm}$, phosphate $50 \mathrm{mmol} / \mathrm{l}$, pH 7,2 emission volume $85 \mathrm{ml}$ ). For the molecular weight determination we used $1 \mathrm{ml}(400 \mathrm{U})$ of the serum of patient 1 ( 2 nd fraction from the column chromatography).

\section{Patients}

Age, sex, and clinical diagnoses of the patients are listed in table 1 .

\section{Patients}

The results of the enzyme activity determinations obtained by the various methods are listed in table 2 . Analysis of the eluates of column chromatography by immunotitration yielded for the first fraction (= "creatine kinase-MM") a mixture of creatine kinase-MM and creatine kinase-BB and for the second fraction (= "creatine kinase-MB") only creatine kinase-BB (tab. 3). The electrophoretic studies on selected serum samples (patients 1, 2, 4, 5 and 6) showed in each case a single creatine kinase band which in contrast to the known isoenzyme distribution of the reference serum, was located between creatine kinase-MM and creatine kinaseMB (fig. 1).

The second fraction from the column chromatography yielded creatine kinase-BB with a sufficient activity. We compared the substrate affinities of creatine kinase-BB prepared and purified from human tissue (14) with that isolated by column chromatography from human serum.

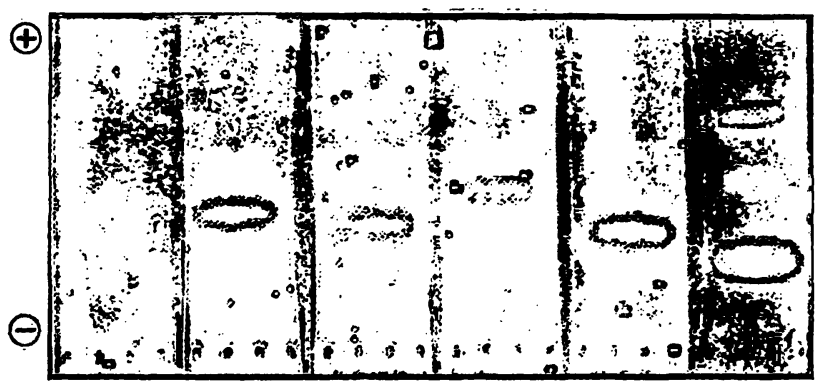

Fig. 1. Electrophoresis showed in each case a single creatine kinase band which, in contrast to the known isoenzyme distribution of the reference serum, was located between creatine kinase-MM and creatine kinase-MB. From left to right: reference serum, patient $1,2,4,5$ and 6 .

Tab. 1. Age, sex and diagnoses of the patients.

\begin{tabular}{|c|c|c|c|}
\hline Patient no. & Age & Sex & Diagnoses \\
\hline 1 & 68 & ఠ & $\begin{array}{l}\text { Coronary heart disease, subclinical diabetes mellitus, hyperlipoproteinemia type } \\
\text { IV, inferior myocardial infarction May 5th 1977: }\end{array}$ \\
\hline 2 & 65 & ○ & Coronary heart disease, subclinical diabetes mellitus. \\
\hline 3 & 57 & $\$$ & $\begin{array}{l}\text { Combined mitral valve defect, stage III-IV, embolism into the ramus interven- } \\
\text { tricularis anterior during cardiac catheterism May } 25 \text { th } 1977 \text {. }\end{array}$ \\
\hline 4 & 28 & \$ & Bronchial asthma \\
\hline $5^{*}$ & 78 & \$ & Çoronary heart disease, diabetes mellitus, pneumonia. \\
\hline 6 & 64 & 9 & $\begin{array}{l}\text { Coronary heart disease, hypertension, hypercholesterolemia, anterior-wall myo- } \\
\text { cardial reinfarction June } 18 \text { th, } 1978 \text {. }\end{array}$ \\
\hline
\end{tabular}

*Kindly supplied by Prof. Dr. Venrath and Dr. Waldecker, Hospital Porz/Rhein. 


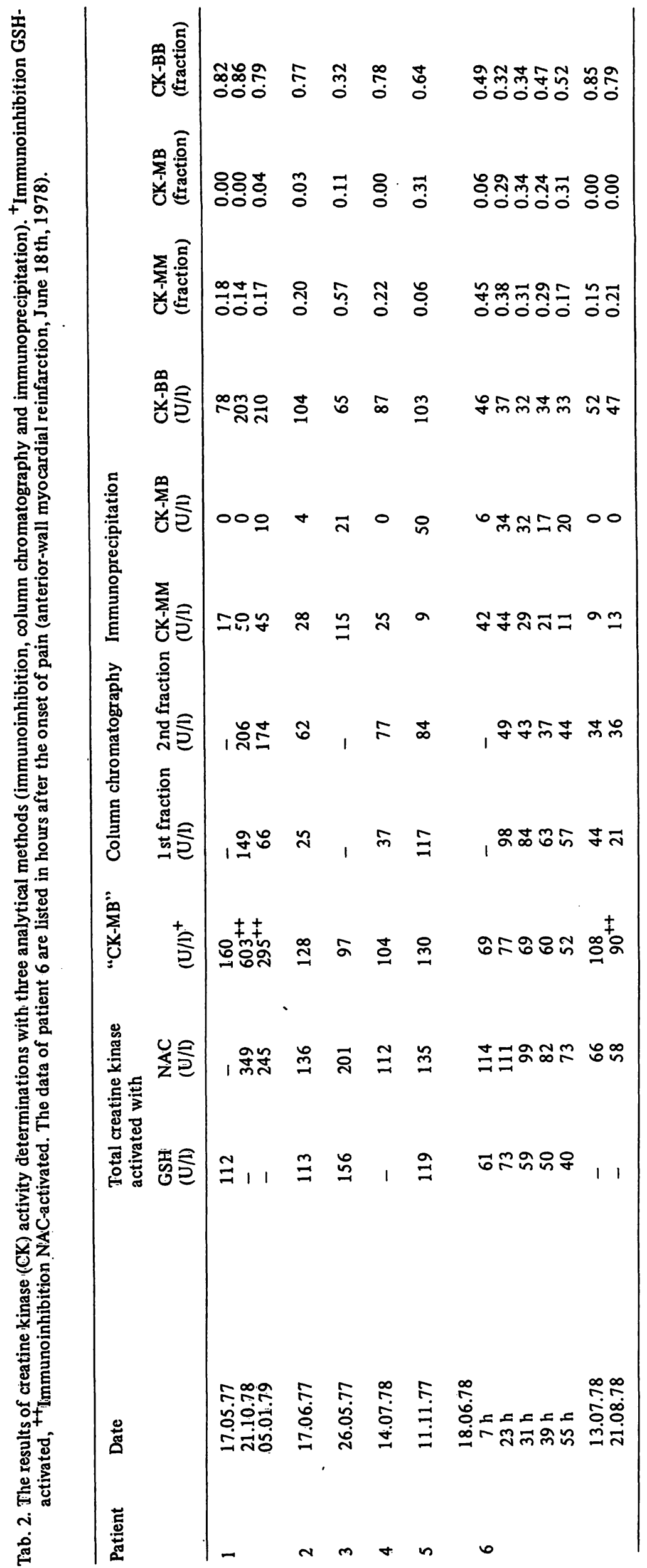


Tab. 3. Analysis of column chromatography eluates by immunoprecipitation gave for the first fraction (= "creatinekinase-MM") a mixture of creatine kinase-MM and creatine kinase-BB and for the second fraction (= "creatine kinase-MB") only creatine kinase-BB.

\begin{tabular}{llcc}
\hline & & $\begin{array}{l}\text { First fraction } \\
\text { "creatine } \\
\text { kinase-MM" }\end{array}$ & $\begin{array}{l}\text { Second fraction } \\
\text { "creatine } \\
\text { kinase-MB" }\end{array}$ \\
\hline Patient 1 & Total CK (U/1) & 105 & 151 \\
& CK-MM (U/1) & 42 & 0 \\
Patient 2 & CK-BB (U/1) & 63 & 151 \\
& Total CK (U/1) & 25 & 62 \\
& CK-MM (U/1) & 25 & 0 \\
Patient 4 & CK-BB (U/1) & 0 & 62 \\
& Total CK (U/1) & 37 & 77 \\
& CK-MM (U/1) & 16 & 0 \\
& CK-BB (U/1) & 21 & 77 \\
\hline
\end{tabular}

The differences in substrate affinities of both enzymes for creatine phosphate and adenosine diphosphate are presented in table 4.

A molecular weight of 250,000 Daltons was determined for the atypical creatine kinase-BB by gel filtration (fig. 2). This value was reproducible both for the native serum and

Tab. 4. The differences of the substrate affinity (Michaelis constants) of creatine kinase-BB from human tissue and macro-creatine kinase-BB (Results of Lineweaver-Burk plot).

\begin{tabular}{|c|c|c|c|c|}
\hline \multirow[t]{2}{*}{ Substrate } & \multicolumn{2}{|c|}{$\begin{array}{l}\text { CK-BB }^{+} \\
\text {from human } \\
\text { tissue }\end{array}$} & \multicolumn{2}{|c|}{ Macro-CK-BB } \\
\hline & $+25^{\circ} \mathrm{C}$ & $+30^{\circ} \mathrm{C}$ & $+25^{\circ} \mathrm{C}$ & $+30^{\circ} \mathrm{C}$ \\
\hline & \multicolumn{4}{|c|}{$K_{\mathrm{m}}(\mathrm{mmol} / \mathrm{l})$} \\
\hline Creatine phosphate & - & 0.71 & 2.23 & 2.44 \\
\hline $\begin{array}{l}\text { Adenosine diphos- } \\
\text { phate }\end{array}$ & - & 0.11 & 0.22 & 0.20 \\
\hline
\end{tabular}

+ after Szász (14) for the second fraction from the column chromatography. A molecular weight of 85,000 Daltons was determined for creatine kinase-BB obtained from myometrial smooth muscle.

We were able to examine the serum samples from patient 1 over a period of 20 months. Creatine kinase-BB was detected regularly throughout this time, though the level of the activity varied. No creatine kinase-B activity was found with the immunoinhibition test in this patient's three children.

In patient 6 we were able to examine the serum samples shortly after an acute myocardial infarction ( 7 hours after the onset of pain) and to study them over 3 days at short intervals. The immunotitration confirmed creatine kinase-MB activity only during the acute phase of infarction; no creatine kinase-MB was detected in the convalescence period. Creatine kinase-BB was, however, found to be constant in all samples and in all phases.

\section{Discussion}

The atypical creatine kinase activity was studied by 4 different analytical methods (immunoinhibition, immunotitration, column chromatography, and electrophoresis) for its relationship to the known isoenzyme distribution pattern. The results obtained by each of the 4 methods are contradictory and could give rise to misinterpretations.

The immunoinhibition seems to show in all 6 patients an exceptionally high creatine kinase-MB content. However, after inhibition of the creatine kinase-M subunits, this method measures only the remaining creatine kinase-B subunit activity, regardless of whether this is to be attributed to creatine kinase-MB or creatine kinase-BB. In all the samples studied by immunotitration, however, the creatine kinase activity could be identified. as due primarily to the isoenzyme creatine kinase-BB.

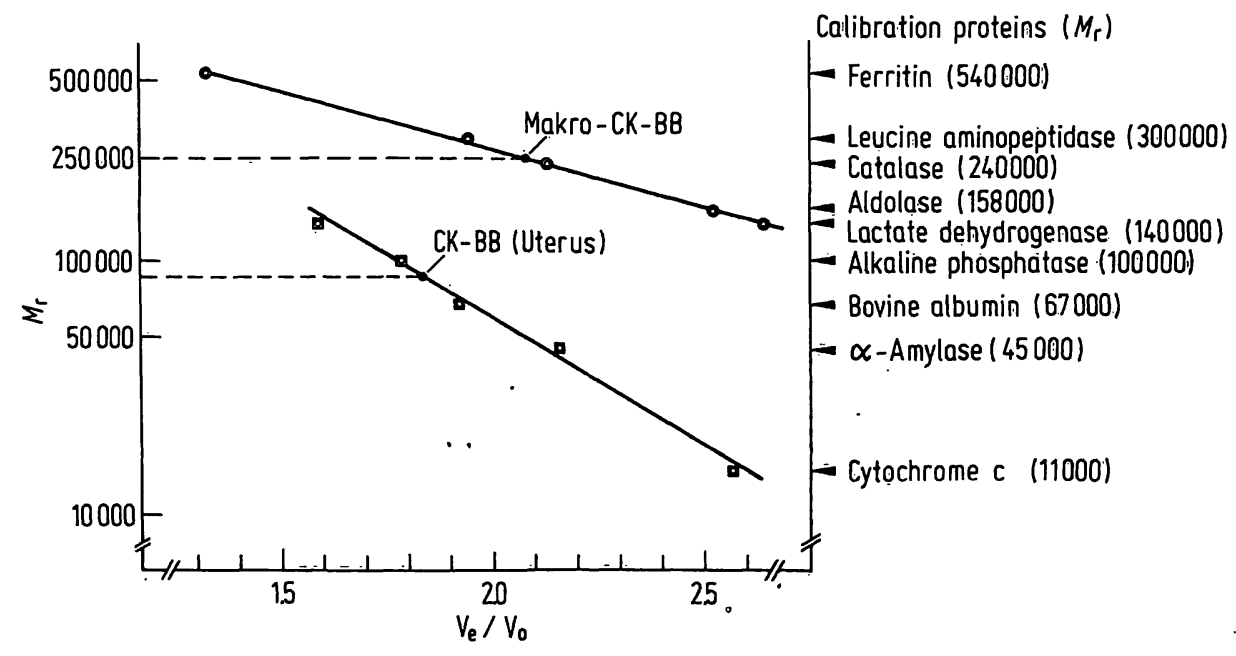

Fig. 2. A molecular weight of $M_{\mathrm{r}} 250,000$ was determined for the atypical creatine kinase-BB (Sepharose $6 \mathrm{~B}$ ) $\odot$ - $\odot$ ) and of $M_{\mathrm{r}} 85,000$ for tissue creatine kinase-BB (myometrial smooth muscle, Sephadex $\mathrm{G} 200$ 回—回) by gel filtration. 
The use of Mercer's modification (13) of column chromatography also simulates a high creatine kinase-MB content. Specific testing of the eluates with immunotitration gave for the first fraction ("creatine kinase-MM") a mixture of creatine-kinase-MM and creatine kinase- $\mathrm{BB}$, and for the second fraction ("creatine kinase-MB") only creatine kinase-BB. The atypical electrophoretic location - all the enzyme activity was located in one band between creatine kinase-MM and creatine kinase-MB - indicates a changed mobility of the variant creatine kinase activity. This altered mobility is also the reason that the column chromatography simulates "creatine kinase-MB" activity in the eluate with the high salt content.

The atypical migration of the enzyme activity is obviously due to its high molecular weight $\left(M_{\mathrm{r}}=250,000\right)$ compared to the molecular weight of native creatine kinase isoenzymes $\left(M_{\mathrm{r}}=80,000,(15,16)\right)$. Urdal \& Landaas (5) have detected a binding of serum creatine kinase-BB to immunoglobulin G. As shown by JockersWretou \& Plessing (8), this is also the case for 5 of the six reported patients. The altered Michaelis constants of the creatine kinase-BB enzyme thus could be explained by steric hindrance.
The total creatine kinase activities are as a rule elevated, but normal activities (see patient 6 ) do not exclude presence of creatine kinase-BB. Since on the whole elevated total creatine kinase activities motivate isoenzyme differentiation, the frequency of patients with this phenomenon may be greater than indicated by the patient material examined so far (Lang et al. (2) 1 : 1000, Ljungdahl et al. (4) 1: 800, Urdal et al. (5) $5: 310$, our observation $6: 2000$ patients). Until now the study of relatives (patient 1 , see also l.c. (2)) has given no evidence for a familial-genetic disposition. With few exceptions (patient 4, see also l.c. $(2,4)$ ), the patients involved are elderly (average age 66.4 years). The sex distribution shows a bias toward women, if the data from comparable studies $(2,4,5,6)$ are included (female:male $=31: 8)$.

\author{
Addendum \\ In the meantime two additional reports due to the problem of \\ macro-creatine kinase-BB are published: \\ Stein, W. \& Bohner, J. (1979), Clin. Chem. 25, 1513-1514. \\ Bohner, J., Stein W., Kuhlmann, E. \& Eggstein, M. (1979), \\ Clin. Chim. Acta 97, 83-88.
}

\section{References}

1. Klapdor, R. \& Harm, K. (1978) Dtsch. Med. Wochenschr. 103, 1665-1671.

2. Lang, H., Würzburg, U., Neumeier, D., Knedel, M., Prellwitz, W., Kattermann, R., Schlebusch, H. \& Schürmann, J. (1978) Klin. Wochenschr. 56, 641-646.

3. Sax, S. M., Moore, J. J., Giegel, J. L. \& Welsh, M. (1976) Clin. Chem. 22, 87-91.

4. Ljungdahl, L. \& Gerhardt, W. (1978) Clin. Chem. 24, 832834.

5. Urdal, P. \& Landaas, S. (1979) Clin. Chem. 25, 461-465.

6. Bauer, K., Hopmeier, P., Muhar, U., Gabl, F., Fischer, M., Schuster, F. \& Deutsch, E. (1979) J. Clin. Chem. Clin. Biochem. 17,141 .

7. Chemnitz, G., Jockers-Wretou, E., Schmidt, E., Schmidt, F. W. \& Lobers, J. (1979) J. Clin. Chem. Clin. Biochem. $17,141$.

8. Jockers-Wretou, E. \& Plessing, E. (1979) J. Clin. Chem. Clin. Biochem. 17, 731-737.
9. German Society for Clinical Chemistry: (1977) J. Clin. Chem. Clin. Biochem. 15, 255-266.

10. Würzburg, U., Hennrich, N. \& Lang, H. (1976) Klin. Wochenschr. 54, 357-360.

11. Würzburg, U., Hennrich, N., Orth, H. D., Lang, H., Prellwitz, W., Neumeier, D., Knedel, M. \& Rick, W. (1977) J. Clin. Chem. Clin. Biochem. 15, 131-137.

12. Jockers-Wretou, E., Grabert, K. \& Pfleiderer, G. (1975), Clin. Chim. Acta 13, 85-88.

13. Mercer, D. W. (1974) Clin. Chem. 20, 36-40.

14. Szasz, G. \& Gruber, W. (1978) Clin. Chem. 24, 245-249.

15. Dawson, D. M., Eppenberger, H. M. \& Kaplan, N.O. (1967) J. Biol. Chem. 242, 210-217.

16. Lee, C. S., Nicholson, G. A. \& O'Sullivan, W. J. (1977) Aust. J. Biol. Sci. 30, 507-517.

\section{Dr. G. Chemnitz}

Division of Gastroenterology and Hepatology Department of Internal Medicine

Medizinische Hochschule Hannover

Karl-Wiechert-Allee 9

D-3000 Hannover 61 
